\title{
A COMPERATIVE STUDY ON RATIO OF CALCIUM AND PHOSPHORUS IN SERUM AND URINE AMONG PRE AND POSTMENOPAUSAL WOMEN.
}

\section{Ewanmihaka Pakma}

Apurba Sarkar*

\section{Martin Luther Christian University, Dongktieh, Nongrah, East Khasi Hills,} Shillong, Meghalaya-7933006.

Viral Research \& Diagnostic Laboratory, AGMC \& GBP Hospital, Kunjavan, Agartala, Tripura-799006. ${ }^{*}$ Corresponding Author

\section{Dr. Suresh Babu}

Padmashree Institute of Clinical Research, Bangalore - 56 .

ABSTRACT Osteoporosis is a bone disease resulting in reduction in bone mass and the bone become susceptible for fracture. The major factor involved in the development of osteoporosis includes, low calcium intake or decrease in Calcium absorption rate in aged population, bone strength in later life depends on development of bones earlier in life, adequate calcium intake during youth is essential to achieve peak bone mass. The Serum Calcium and Phosphorus, Urinary Calcium and Phosphorus were estimated by spectrophotometrically by O-cresolphthalein and Phosphomolybdate method respectively. Urinary creatinine was estimated by Spectrophotometric Jaffe's reaction. In our study, Urinary Calcium excretion was significantly increased with that of premenopausal woman of Indian sub population. Present study is an attempt to underscore urinary calcium quantification does increase diagnostic sensitivity by measuring it as derive parameter - CCR. It could as well be considered as an indicator for therapeutic intervention by studying large pre and postmenopausal woman population.

\section{KEYWORDS : Menopause, Calcium, Phosphorus, Osteoporosis.}

\section{INTRODUCTION}

Menopause, which is also referred as burning out of the ovaries, when estrogen production falls below a critical value, which can no longer inhibit the production of the gonadotropins such as FSH and LH. Instead, the gonadotropins FSH and LH (mainly FSH) are produced after menopause in large and continuous quantities, but as the remaining primordial follicles become atretic, the production of estrogen by the ovaries falls virtually to zero. Throughout $\alpha$ woman's reproductive life, about 400 of the primordial follicles grow into mature follicles and ovulate, and hundreds of thousands of ova degenerate. At about age 45 years, only a few primordial follicles remain to be stimulated by FSH and $\mathrm{LH}$, and the production of estrogen by the ovaries decreases as the number of primordial follicles approaches zero. The loss of estrogen often causes marked physiological changes in the function of the body ${ }^{\text {[1] }}$. Women are at greater risk of developing osteoporosis than men, particularly in menopausal state, as they need greater amounts of certain nutrients than men, particular iron and calcium. Menstruation, pregnancy, lactation and menopause are times of increased nutritional demand. The major factor involved in the development of osteoporosis includes, low calcium intake or decrease in Calcium absorption rate in aged population, bone strength in later life depends on development of bones earlier in life, adequate calcium intake during youth is essential to achieve peak bone mass ${ }^{[2]}$. Development of peak bone mass and premenopausal bone loss is determined by the menstrual status of women ${ }^{[3]}$. Decline in bone mass with age becomes accelerated during menopause. Menopausal bone loss refers to the accelerated bone loss that occurs during the premenopausal age and after the final menses ${ }^{[4]}$. Bone as a dynamic tissue constantly undergoes formation and re-absorption and the process is balanced in healthy adults ${ }^{[5]}$. Bone is a connective tissue that provides mechanical support to the body vital organs and act as reservoir of calcium and phosphate as $99 \%$ of calcium and $85 \%$ of phosphate are present in skeleton ${ }^{[6]}$. Peak bone mass is achieved during the third decade of life which gradually declines leading to osteopenia (low bone mass) which predisposes to osteoporosis ${ }^{[1]}$. Bone texture development and re-absorption is analyzed by measuring the concentration of bone turnover markers in blood or urine (or both). However bone reabsorption markers are considered as strong predictors of bone loss as compared to bone formation markers ${ }^{[8,9]}$. Bone mass can be determined by bone mineral density measurements for assessing fracture risk and diagnosing osteoporosis ${ }^{[10]}$. Symptoms of postmenopausal syndrome includes, hot flashes characterized by extreme flushing of the, vasomotor instability, irregularity in blood pressure, fatigue, nervousness, emotional outburst like crying and anger, mental depression, insomnia, palpitation, vertigo, headache. The diminishing synthesis of estrogen leads to osteoporosis and atherosclerosis in woman.

Osteoporosis is a bone disease resulting in reduction in bone mass and the bone become susceptible for fracture. ${ }^{[11]}$.

\section{AIMS AND OBJECTIVE OF THE STUDY}

The study will be conducted with the following objectives.

1. To assess the status of concurrent serum and urinary Calcium and phosphorous levels in pre and postmenopausal woman.

2. To correlate these bio-chemicals as an early marker of osteoporosis in postmenopausal women.

\section{MATERIALS}

Patients who were attending at Padmashree Diagnostics, Department of Gynaecology, Vijayanagar, Main Road, Bengaluru, for elective diagnosis and treatment, who were belonging to pre and postmenopausal woman recruited for this study. After complete explanation of the study to the subjects, a written informed consent was obtained from subjects. A total of seventy pre and postmenopausal women (35 each) was recruited for the present study. Following criteria were used to include or exclude subjects for the study:

Table - I Inclusion and Exclusion criteria

\begin{tabular}{|c|c|c|}
\hline Selection Criteria & \begin{tabular}{|l|} 
Pre \\
Menopausal \\
\end{tabular} & \begin{tabular}{|l|} 
Post- \\
Menopausal
\end{tabular} \\
\hline \multicolumn{3}{|l|}{ Inclusion Criteria : } \\
\hline Age in Years & $25-45$ & $48-67$ \\
\hline Gender & Female & Female \\
\hline Healthy Volunteers & Yes & No \\
\hline $\begin{array}{l}\text { Menopausal woman who had } \\
\text { cessation of menses for at least } \\
\text { one year duration }\end{array}$ & - & Yes \\
\hline
\end{tabular}




\begin{tabular}{|c|c|c|}
\hline Woman who had menses at regular duration & Yes & - \\
\hline Not on Hormone Replacement Therapy & Yes & Yes \\
\hline \multicolumn{3}{|l|}{ Exclusion Criteria: } \\
\hline $\begin{array}{l}\text { Metabolic diseases like hypo/ } \\
\text { hyperparathyroidism, Hyperthyroidism and } \\
\text { diabetes mellitus. }\end{array}$ & No & No \\
\hline $\begin{array}{l}\text { Auto immune diseases like SLE and rheumatoid } \\
\text { arthritis }\end{array}$ & No & No \\
\hline $\begin{array}{l}\text { Surgery like gastrointestinal resection or } \\
\text { malabsorption }\end{array}$ & No & No \\
\hline Chronic liver or Renal diseases & No & No \\
\hline $\begin{array}{l}\text { Drugs which may affect bone metabolism like, } \\
\text { Glucocorticoids, aluminium containing antacids, } \\
\text { Frusemide, bisphosphonate, calcium, Vitamin A, } \\
\text { Vitamin D, Calcitonin, lithium, antiepileptics and } \\
\text { anticoagulant, hypercalcaemia of malignancy }\end{array}$ & No & No \\
\hline $\begin{array}{l}\text { Chronic granulomatous disease like sarcoidosis } \\
\text { and tuberculosis }\end{array}$ & No & No \\
\hline Paget's disease of bone & No & No \\
\hline Cigarette smoking, Alcohol abuse & No & No \\
\hline $\begin{array}{l}\text { History of recent fractures ( in the earlier six } \\
\text { months) }\end{array}$ & No & No \\
\hline
\end{tabular}

Specimen handling and analysis

The blood and corresponding urine specimens received in the laboratory and the blood specimen was centrifuged (1800 x g $/ 15 \mathrm{mins}$ ) to separate the cellular components and the cell free serum processed for the analysis of routine biochemical parameters sought by the treating clinicians. Remaining specimens were aliquoted, labelled and stored at $-20^{\circ} \mathrm{C}$ till further analysis. Aliquots of specimens, once thawed were used for the analysis on the same day and not be subjected to repeat freezing and thawing to avoid any pre-analytical errors.

\section{METHODS}

Sampling method: Random Sampling

\section{ANALYTICAL METHODS:}

Serum Calcium and Phosphorus, Urinary Calcium and Phosphorus were estimated by spectrophotometrically by $\mathrm{O}$ cresolphthalein and Phosphomolybdate method respectively ${ }^{[12]}$. Urinary creatinine was estimated by Spectrophotometric Jaffe's reaction ${ }^{[12]}$.

\section{STATISTICAL ANALYSIS}

SPSS Version 19.0 Data analysis package was used and applied to analyse the obtained data after discussion with the Biostatistician. All the values were expressed in mean \pm SD. Statistical comparison was performed using student t test. The student's 't' test ${ }^{*} p<0.05 ;{ }^{* *} p<0.01 ;{ }^{* *} p<0.001$ was considered as significant.

\section{ASSAY PROTOCOLS}

The analytes of interest in serum and urine were assayed by the following methods. Details regarding the assay methods with respect to the precise volumes of specimens / reagents and assay conditions etc., is provided in Table - II.

\begin{tabular}{|l|l|l|l|}
\hline \multicolumn{3}{|l|}{$\begin{array}{l}\text { Table - II: Summary of biochemical assay settings and } \\
\text { performance characteristics }\end{array}$} \\
\hline $\begin{array}{l}\text { ASSAY } \\
\text { PARAMETERS }\end{array}$ & CALCIUM & PHOSPHORUS & $\begin{array}{l}\text { UR. } \\
\text { CREATININE }\end{array}$ \\
\hline Type of Specimens & $\begin{array}{l}\text { Serum \& } \\
\text { Urine }\end{array}$ & Serum \& Urine & Urine \\
\hline Assay Method & End Point & End Point & End Point \\
\hline $\begin{array}{l}\text { Sample Volume } \\
\text { (Normal) in } \mu \mathrm{l}\end{array}$ & 2 \& & $2 \& 2$ & 15 \\
\hline $\begin{array}{l}\text { Sample Volume } \\
\text { (Decrease) in } \mu \mathrm{l}\end{array}$ & -- & -- & -- \\
\hline $\begin{array}{l}\text { Sample Volume } \\
\text { (Increase) in } \mu \mathrm{l}\end{array}$ & -- & -- & -- \\
\hline Sample Dilution & -- & -- & Yes \\
\hline
\end{tabular}

\begin{tabular}{|c|c|c|c|}
\hline \begin{tabular}{|l} 
Single Reagent \\
Chemistry
\end{tabular} & Yes & Yes & Yes \\
\hline \begin{tabular}{|l|} 
Two Reagent \\
Chemistry
\end{tabular} & -- & -- & -- \\
\hline $\mathrm{Rl}$ in $\mu \mathrm{l}$ & 20 & 90 & 750 \\
\hline R2 in $\mu \mathrm{l}$ & 20 & 38 & -- \\
\hline $\begin{array}{l}\text { Wavelength } \\
\text { Primary } \\
\text { (in nm) }\end{array}$ & 552 & 340 & 505 \\
\hline $\begin{array}{l}\text { Wavelength } \\
\text { Secondary } \\
\text { ( in } \mathrm{nm} \text { ) }\end{array}$ & 629 & 659 & \\
\hline Calibration Method & Single Point & Single Point & \begin{tabular}{|l|} 
Single \\
Point
\end{tabular} \\
\hline Calibration Type & Linear & Linear & Linear \\
\hline $\begin{array}{l}\text { Calibrator (CRM) } \\
\text { value }\end{array}$ & 9.96 & 9.15 & 190 \\
\hline Traceability of CRM & GC-MS & GC-MS & GC-MS \\
\hline Multi Point Method & - & - & - \\
\hline \begin{tabular}{|l|} 
(I - VI Stds) \\
\end{tabular} & & & \\
\hline Std I & - & - & - \\
\hline Std II & - & - & - \\
\hline Std III & - & - & - \\
\hline Std IV & - & - & - \\
\hline SD limit & 0.1 & 0.1 & 0.1 \\
\hline Duplicate limit & 150 & 500 & 100 \\
\hline Sensitivity limit & 2100 & 50 & 2000 \\
\hline Äbs limit (inc/dec) & Inc & Inc & Inc \\
\hline${ }^{\star}$ Unit Expression & $\mathrm{mg} / \mathrm{dL}$ & $\mathrm{mg} / \mathrm{dL}$ & $\mathrm{mg} / \mathrm{dL}$ \\
\hline \multicolumn{4}{|c|}{ Specific Characteristics of Ässay } \\
\hline Detection limit & $0.2-20$ & $0.3-20$ & $0.2-20$ \\
\hline \begin{tabular}{|l|} 
Reference Interval \\
Serum
\end{tabular} & $9.3 \pm 1.3$ & $3.6 \pm 1.3$ & - \\
\hline \begin{tabular}{|l} 
Reference interval \\
Urine \\
\end{tabular} & $14.3 \pm 19.4$ & $3.6 \pm 1.3$ & $95 \pm 62.5$ \\
\hline \multicolumn{4}{|l|}{$\begin{array}{l}\text { Precision: Mean/ } \\
\text { SD/ CV\% }\end{array}$} \\
\hline \begin{tabular}{|l|} 
Linearity: \\
(Slope/ Correl/ \\
Coeffi)
\end{tabular} & $1.0260 / 0.9996$ & $1.054 / 0.9998$ & $\begin{array}{l}1.024 / \\
0.998\end{array}$ \\
\hline Reagent Source & Commercial & Commercial & $\begin{array}{l}\text { In-House } \\
\text { prep }\end{array}$ \\
\hline Instrument Used & $\begin{array}{l}\text { COBAS } \\
\text { INTEGRA } 400 \\
\text { PLUS }\end{array}$ & $\begin{array}{l}\text { COBAS } \\
\text { INTEGRA } \\
400 / 400 \\
\text { PLUS } \\
\end{array}$ & $\begin{array}{l}\text { Spectropho } \\
\text { tometer }\end{array}$ \\
\hline
\end{tabular}

\section{RESULTS AND DISCUSSION}

The present study was carried out to assess the status of calcium and phosphorus in serum and urine, urinary creatinine and derived parameter, urinary calcium/creatinine ratio (CCR) and phosphorus/creatinine ratio (PCR). The patients were recruited for the study at the Padmashree Diagnostics, Department of Gynecology, Vijayanagar, Bangalore, The study initiation started after obtaining the written informed consent. The study population consisted of 70 participants of premenopausal $(n=35)$ and postmenopausal women ( $n=35$ ), mean age of (Fig: 1) $38.0 \pm 4.0$ and $54.4 \pm 4.6$ respectively.

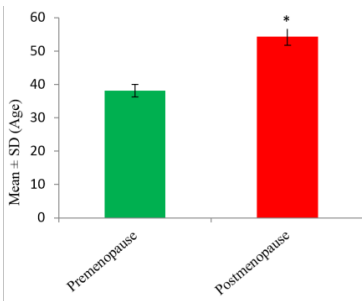

Fig: 1 Histogram represents the age distribution among the pre and post menopause women. Values expressed as Mean 
\pm SD. Student's't' test: ${ }^{*}: p<0.05 ;{ }^{* *}: p<0.01: \quad{ }^{* * *}: p<$ 0.001 . $^{*}$

It is apparent that Post-menopausal Osteoporosis becoming an important debilitating problem worldwide and it has increased the risk of sudden and unexpected fractures ${ }^{[13]}$. Accordingly, with an emphasis on the required sensitivity of the assay methods, the present study was carried out on drug naive patient population suspected to be suffering from osteoporosis, by validating available analytical methods for serum and urinary parameters that are often used in laboratory medicine.

The biochemical investigations such as Serum calcium and phosphorus, Urinary calcium and phosphorus and creatinine were studied. The Functional role of Calcium in human body, has received substantial interest in both the medical literature and its role in osteoporosis and several other chronic diseases, including hypertension and colon cancer ${ }^{[14,20]}$. The amount of calcium needed is also affected by the decrease in intestinal absorption that occurs with age ${ }^{[15]}$.

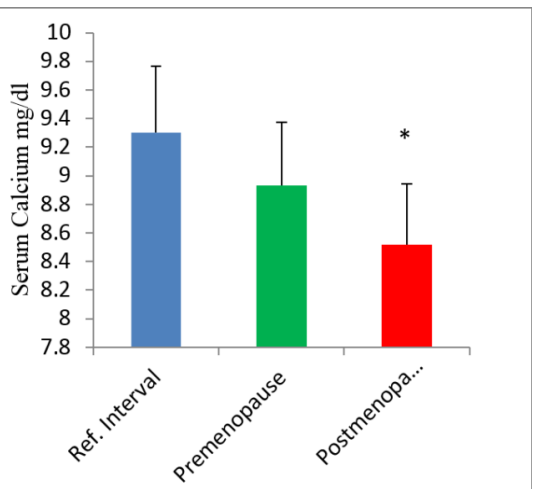

Fig: 2 Histogram represents the Serum Calcium among the pre and post menopause women. Values expressed as Mean \pm SD. Student's't' test: ${ }^{\star}: \mathrm{p}<0.05 ;^{* *}: \mathrm{p}<0.01:{ }^{* *}: \mathrm{p}<0.001$.

As a part of present study, the observed serum calcium was significantly lower $\left({ }^{*} p<0.05\right)$ in postmenopausal woman compared to premenopausal woman. $8.9 \pm 1.2 \mathrm{mg} / \mathrm{dL}$ and 8.5 $\pm 1.4 \mathrm{mg} / \mathrm{dL}$ respectively (Fig 2 ). However, the observed serum calcium level in both the group was within the reference interval.

Phosphorus and magnesium are among minerals that have been proposed as having an important role in bone metabolisms. Phosphorus, as phosphates combine with calcium ions to form Hydroxyapatite, the major inorganic molecule in teeth and bones ${ }^{[16,17]}$. In present study, there was a significant $\left({ }^{*} p>0.05\right)$ increase in serum phosphorus concentration in premenopausal women compared to postmenopausal women $3.9 \pm 0.6 \mathrm{mg} / \mathrm{dL} \& 3.7 \pm 0.6 \mathrm{mg} / \mathrm{dL}$ respectively (Fig 3 ). Serum phosphorus showed a tendency to reduce might be due to early part of bone remodelling due to decrease in estrogen secretion. The outcome underscores that early medical intervention certainly minimizes the osteoporotic complications ${ }^{[17,18]}$.

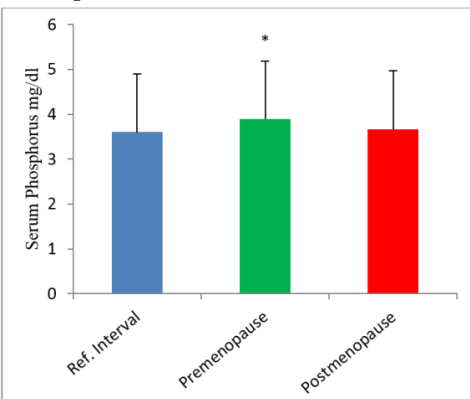

Fig: 3 Histogram represents the Serum Phosphorus among the pre and post menopause women. Values expressed as Mean \pm SD. Student's't' test: ${ }^{*}: p<0.05 ;{ }^{* *}: p<0.01:{ }^{* * *}: p<$ 0.001 .

It is important to monitor renal function to monitor various urinary biomarkers to rule out or to observe the manifestation by follow-up. By and large, biochemical investigations such as urea, creatinine, urinary creatinine clearance etc., explain the pathophysiology of the biochemical process ${ }^{[18]}$.

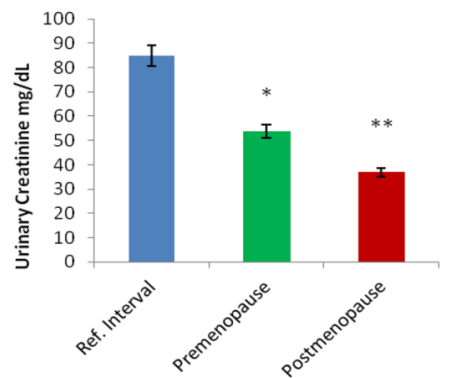

Fig: 4 Histogram represents the Urinary Creatinine among the pre and post menopause women. Values expressed as Mean \pm SD. Student's't' test: ${ }^{*}: p<0.05 ;{ }^{* *}: p<0.01:{ }^{* * *}: p<$ 0.001 .

It has also been considered as gold standard of practice for clinicians to normalize urinary excretion of many different biomarkers/abnormal metabolites to urine creatinine in chronic conditions such as microalbuminuria in diabetes mellitus and proteinuria in nephrotic syndromes. Lack of normalization may lead to falsely low biomarker/abnormal metabolites concentration interpretation in glomerular filtration rate. In fact, spot assessments of urinary biomarkers of chronic kidney diseases normalized to urine creatinine concentrations have succeeded to replace $24 \mathrm{hrs}$ urinary collections in many instances ${ }^{[10,17]}$.

Consequently, in the present study the pre and postmenopausal woman had significantly low creatinine excretion rate with that of normal reference interval $37.0 \pm$ 27.3 and $53.7 \pm 14.2 \mathrm{mg} / \mathrm{dL}$ respectively (Fig: 4 ). However, the used available reference interval value had 30 to $45 \%$ higher than the pre and postmenopausal woman group urinary creatinine, which is rather confounding. The observed decrease in urinary creatinine may be due to the ref interval for this parameter referred to in this study, which may not be the representative of the patient population studied or it is from normal general population.

The term of urinary calcium and phosphorus normally reported by relating to urinary creatinine excretion rate, Since, the relatively constant amount of creatinine excretion in urine proportional to the muscle mass of an individual ${ }^{[19]}$.

Hence, in present study the estimated pre and postmenopausal woman urinary calcium and phosphorus level are normalized to creatinine excretion rate and compared with respective normal reference interval.

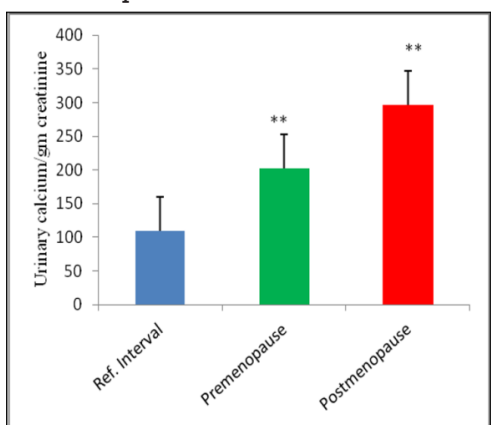

Fig: 5 Histogram represents the Urinary Calcium/creatinine 
g the pre and post menopause women. Values ratio among the pre and post menopause women. Values
expressed as Mean \pm SD. Student's't' test: ${ }^{*}: p<0.05 ;{ }^{* *}: p$ $<0.01:{ }^{* * *}: p<0.001$.

As shown in Fig 5 urinary excretion of calcium was significantly elevated from reference interval in pre and postmenopausal women. The concentration was $202.9 \pm$ $155.6 \mathrm{mg} / \mathrm{g}$ creatinine and $297.0 \pm 378.4 \mathrm{mg} / \mathrm{gm}$ creatinine respectively.

As shown in Fig 6 urinary excretion of phosphorus was significantly elevated from that of reference interval in pre and post menopausal woman population by $\left({ }^{*} p<0.01\right)$ and $\left({ }^{*} p\right.$ $<0.05$ ) respectively. The concentration was $884.9 \pm 907.3 \mathrm{mg} / \mathrm{g}$ creatinine in premenopausal women and $657.1 \pm 465 \mathrm{mg} / \mathrm{g}$ creatinine in postmenopausal women.

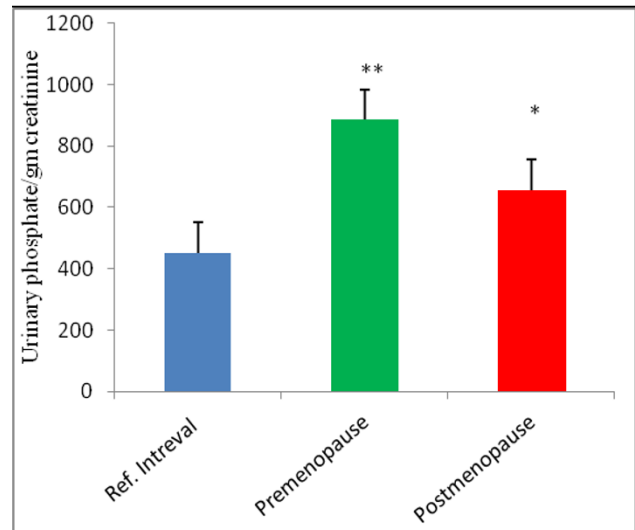

Fig: 6 Histogram represents the Urinary Phosphorus/ creatinine ratio among the pre and post menopause women. Values expressed as Mean \pm SD. Student's't' test: * $p<$ $0.05 ;^{* *}: p<0.01:^{* * *}: p<0.001$.

Several researchers speculating that high dietary items are rich source of phosphorus content which is good enough to normal life when compared other elements. It is unlikely to find any phosphorus deficient in human population. However, the urinary excretion of phosphorus per gram creatinine does give guidance to monitor in various diseases progression like osteoporosis in post-menopausal woman ${ }^{[21]}$. As shown in Fig 6 urinary phosphorus excretion rate quite hilariously higher in premenopausal woman than postmenopausal woman it needs to be explained.

\section{DISCUSSION}

Details regarding the precise volumes of specimens/ reagents and assay conditions, detection range etc., is provided in (Table - II). The findings on descriptive statistics of various analysed and derived test parameters of serum and urine (Table-IIIB) in pre and postmenopausal woman of drug naïve cases studied as two group ( $n=35$ each) with respective of age differences (Table - IIIA) sub classified with respective reference intervals. In our current study, the distribution of data among pre and postmenopausal group (Table - IIIB) have shown significant difference between the groups and it underscores that studying serum and urinary calcium and phosphorus and its relevance to relate the finding with CCR and PCR is increased the diagnostic sensitivity to figure out the pathophysiology in postmenopausal osteoporosis population.

The present study involving the analysis of serum and urinary calcium and phosphorus comprising a pre and postmenopausal woman $(\mathrm{n}=35 \mathrm{each})$. The finding was compared with available reference intervals on pre and postmenopausal women. Thus, the present randomized control, open-blinded and cross-sectional study was an attempt to further validate the low cost test do has diagnostic sensitivity to identify the disease and to monitor the bone recovery process. Our study once again underscores the screening for urinary calcium and phosphorus in pre and postmenopausal women may help us in identifying the individuals who are at increased risk for frequent bone fracture. In present study the Serum calcium level of postmenopausal woman group had lower limit of normal when compared to premenopausal woman (Fig: 2). The urinary calcium: creatinine ratio has increased the diagnostic sensitivity (Fig: 5 ). The findings from this study between pre and postmenopausal woman serum phosphorus and urinary phosphorus: creatinine ratio surprisingly found to have very conspicuous, wherein premenopausal woman had suboptimal level of serum phosphorus than postmenopausal woman as compared to reference interval. Conversely, the derived parameter PCR increased than postmenopausal woman as compared to reference interval.

\section{CONCLUSION}

Osteoporotic fractures are one of the main causes of morbidity and mortality in India ${ }^{[22]}$. In our study, Urinary Calcium excretion was significantly increased with that of premenopausal woman of Indian sub population. Present study is an attempt to underscore urinary calcium quantification does increase diagnostic sensitivity by measuring it as derive parameter - CCR. It could as well be considered as an indicator for therapeutic intervention by studying large pre and postmenopausal woman population. Early detection and treatment of osteoporosis with available agents can significantly reduce the risk of fractures and associated morbidity and mortality.

\begin{tabular}{|l|l|l|l|l|}
\hline \multirow{2}{*}{$\begin{array}{l}\text { No } \\
\text { No }\end{array}$} & Groups & \multicolumn{2}{|l|}{ Age in years } & $\begin{array}{l}\text { Unpaired t-test } \\
\text { value }\end{array}$ \\
\cline { 3 - 4 } & & Range & Mean \pm SD & $15.27, \mathrm{p}<0.05$ \\
\hline 1 & Pre menopause & $29-46$ & $38.11 \pm 4.30$ & \\
\hline 2 & Post menopause & $47-67$ & $54.40 \pm 4.60$ & \\
\hline
\end{tabular}

Table - III A: Age Distribution Of Pre And Post Menopause Women.

\begin{tabular}{|c|c|c|c|c|c|c|}
\hline \multirow{2}{*}{$\begin{array}{l}\text { Sl } \\
\text { No }\end{array}$} & \multirow{2}{*}{$\begin{array}{l}\text { Parame } \\
\text { ter }\end{array}$} & \multicolumn{2}{|c|}{ Premenopause } & \multicolumn{2}{|c|}{ Postmenopause } & \multirow{2}{*}{$\begin{array}{l}\text { Unpaire } \\
\text { d t test } \\
\text { Value }\end{array}$} \\
\hline & & Range & $\begin{array}{l}\text { Mean } \pm \\
\text { SD }\end{array}$ & Range & $\begin{array}{l}\text { Mean } \pm \\
\text { SD }\end{array}$ & \\
\hline l & & & $8.93 \pm 1.9$ & & $8.5 \pm 1.4$ & \\
\hline 2 & S-P & $3-5$ & 0.6 & $3-$ & 3.7 & \\
\hline 3 & UI & $4-25$ & 8.2 & $\underline{Z}$ & 8.6 & \\
\hline 4 & U-PHOS & $4-99$ & 18.6 & $6-92$ & 21.7 & $03 \mathrm{~B}$ \\
\hline 5 & CCR & $0-1$ & $203 \pm 156$ & $0-$ & $297 \pm 378$ & $<0.01$ \\
\hline 6 & $\overline{\mathrm{PCR}}$ & $0-4$ & $885 \pm 907$ & $0-4$ & $657 \pm 465$ & $<0.01$ \\
\hline
\end{tabular}

Note: $\mathrm{p}<0.05$ significant at $5 \%$ level, $\mathrm{p}>0.05$ not significant at $5 \%$ level

Table - IIIB: Findings of Serum Calcium, Serum Phosphorus, Urinary Calcium, Urinary

\begin{tabular}{|l|l|l|}
\hline SL No. & Parameters & Mean \pm SD \\
\hline 1 & Serum Calcium & $9.3 \pm 1.3$ \\
\hline 2 & Urinary Calcium & $14.3 \pm 19.4$ \\
\hline 3 & Serum Phosphorus & $3.6 \pm 1.3$ \\
\hline 4 & Urinary Phosphorus & $88.0 \pm 67.9$ \\
\hline 5 & Calcium/gm Creatinine & $110 \pm 155.6$ \\
\hline 6 & Phosphorus/gm Creatinine & $452 \pm 557.2$ \\
\hline Table - IIIC: Reference ranges of assay parameters ${ }^{[23,24,25]}$ \\
\hline
\end{tabular}

\section{REFERENCE:}

1. Sobha S.R, Maulshree S, Mehjabin P. et al for the Health Maintenance for Postmenopausal women- American family physician: pg 1/14. Sept1,2008. Available from http://www.aafp.org/afp/2008/0901/p583.html

2. Guyton, Hall. Text Book of Medical Physiology. $12^{\text {th }}$ edition. Saunders Elsevier. 2011.

3. Khan AA, Syed Z. Bone Densitometry in premenopausal women, Synthesis and review. J Clin Densitom, 2004; 7 (1): 85-92.

4. Hernandez CJ, Beaupre GS, Carter DR. A theoretical analysis of the changes in basic multicellular unit activity at menopause. Bone, 2003; 32: 357-363.

5. National Academy press (NAP). (2000). Dietary Reference Intakes for calcium phosphorus, magnesium, vitamin D, and fluoride. Retrieved October 10 
2001,from: http://www.nap.edu/openbook/039063507/html/71.html. Accessed on: $25^{\text {th }}$ October 2020

6. George B O. Urinary and Anthropometrical Indices of Bone density in Healthy Nigerian Adults. J Appl Sci. Environ Mgt, 2003; 7 (1): 19-23.

7. Usman J, Siddiqui H. Osteoporosis in family practice. JPMA, 2003; 53 (9): $433-436$.

8. Osteoporosis Health Centre. Bone mineral density [Web document]. S.I: Health wise; 2007. Available from: URL:http:// www. webmd. com/ hw/ osteopoross/hw3738.asp. Accessed on: $25^{\text {th }}$ October 2020.

9. Cinnamon VanPutte, Jennifer regan, Andrew Russo, Rod Seeley, Trent Stephens, Philip Tate; Seeley's Anatomy \& Physiology; $10^{\text {th }}$ edition; New York; McGraw-Hill; 2014.

10. K Sembulingam, Prema Sembulingam; Essentials of Medical Physiology; $6^{\text {th }}$ Edition; JAYPEE Brothers Medical Publishers (P) LTD; 2012

11. Wu, D.D., Boyd, R.D., Fix, T.J. \& Burr, D.B. 1990. Regional patterns of bone loss and altered bone remodeling in response to calcium deprivation in laboratory rabbits. Calcif. Tissue Int., 47: 18-23.

12. Henry R ed. Clinical Chemistry: Principle and Techniics, $2^{\text {nd }}$ ed New York, NY: Harper \& Row, 1974:723

13. Nieves JW. Nutrition and osteoporosis In: Cummings S, Cosman F, Jamal S, eds. Osteoporosis: an evidence based approach to the prevention and management. Philadelphia American College of Physicians, 2002.

14. Jack SD. Mineral and Metabolic bone disease. Washington Manual Therapeutics. 1998. 29th ed. Philadelphia: Lippincot-Raven 1998: pp.450-51.

15. K Sembulingam, Prema Sembulingam; Essentials of Medical Physiology; $6^{\text {th }}$ Edition; JAYPEE Brothers Medical Publishers (P) LTD; 2012

16. Nordin, B.E.C. 1976. Nutritional considerations. In: Calcium, Phosphate and Magnesium Metabolism. Nordin, B.E.C., ed. p. 1-35. Edinburgh: Churchill Livingstone.

17. Dr C.C. Chatterjee; Human Physiology. $10^{\text {th }}$ edition (Reprint 2002): Medical Allied Agency;2002,p-4-100-4-106

18. Farrel C.E. 'Electrolytes' in Clinical Chemistry Theory. Analysis and Correlation. The C.V Mosby Company. Kaplan L.A, Pesce A.J(Ed).1984; Chap $55 ; 1054$

19. Bilezikian JP, Raisz LG, Rodan GA, eds. Principal of bone biology, $2^{\text {nd }}$ ed. San Diego: academic press 2002

20. Marcus R, Feldman D, Kelsey J, eds. Osteoporosis, $2^{\text {nd }}$ ed. San Diego: academic press, 2001

21. Institute of Medicine, 1997. "Dietary Reference Intakes for Calcium, Phosphorus Magnesium, Vitamin D, and Fluoride", National Academy Press, 1997, p.151-152.

22. Nordin, B.E.C. 1960. Osteomalacia, osteoporosis and calcium deficiency. Clin.Orthop., 17: 235-258

23. Beeler, M.F.and Catrou, P.G.'Disorders of Calcium Management" in Interpretations in Clinical Chemistry A.C.S.P. Press Chicago 1983;34-44

24. Lakatos P, Takacs I, Buki B, Nemeth I. Horvath C.Urinary calcium excretion: normal values for urinary calcium/creatinine ratio in Hungary. Orv Hetil 1997; 138(22):1405-9.

25. Burtis CA,Ashwood ER, BrunsDE. Tietz textbook of clinical chemistry and molecular diagnostics,4th Edition, Philadelphia: Saunders Elsevier, 2006. 